\title{
Evaluation of Protective Potential of Curcuma longa in Induced Aflatoxicosis in Broiler Birds
}

\author{
L. Raja $^{1 *}$, Chandan Kumar Singh ${ }^{3}$, M. Mondal ${ }^{2}$, S. Nety ${ }^{1}$ and K. M. Koley ${ }^{1}$ \\ ${ }^{1}$ Department of Veterinary Pharmacology and Toxicology, College of Veterinary Science and \\ A.H., CGKV, Durg, Chhattisgarh, India \\ ${ }^{2}$ Department of Teaching Veterinary Clinical Complex, Faculty of Veterinary and Animal \\ Sciences, West Bengal University of Animal and Fishery Sciences, Kolkata, India \\ ${ }^{3}$ Department of Veterinary Surgery and Radiology, College of Veterinary Science, Khanapara, \\ Assam Agricultural University, India \\ *Corresponding author
}

\section{A B S T R A C T}

The present study was undertaken to evaluate the ameliorative effects of Curcuma longa rhizome powder $(1 \%)$ in induced aflatoxicosis in broiler chicken. In this study,

\section{Keywords}

Aflatoxicosis,

Biochemical

changes, Broilers,

Curcuma longa,

Oxidative stress.

Article Info

Accepted:

04 September 2017

Available Online:

10 October 2017 commercially available broiler chickens of Vencobb strain were reared from day one to forty two days in the deep litter system of management and the birds were divided into three groups. Normal feed tested free of aflatoxin (AF), was given to the control (Group1). Aflatoxin (1 ppm) was supplemented with the feed to Group 2 and Curcuma longa $(1 \%)+\mathrm{AF}$ was supplemented with the feed to Group 3. Biochemical parameters like Total serum protein, Albumin, Globulin, Albumin / Globulin ratio, blood glucose, AST, ALT, uric acid and serum creatinine were estimated. The results showed that the supplementation of $C$. longa $(1 \%)+\mathrm{AF}$ partially restored the biochemical alterations induced by the AF. At the sixth week of age, two birds from each replicate were sacrificed to evaluate the oxidative stress parameters (reduced glutathione levels, Lipid peroxidation, Catalase) in the liver and kidney. The results showed that the AF causes a marked oxidative stress in comparison to control, which was partially reversed by the supplementation of the $C$. longa $(1 \%)$ in the feed. However, C. longa significantly improved the antioxidant status in induced aflatoxicosis and partially protected against the cytotoxic effects of $\mathrm{AFB}_{1}$ in broiler birds.

\section{Introduction}

Aflatoxicosis continues to be a major problem in many parts of the world, in spite of better understanding and sufficient advances. Aflatoxicosis causes poor production performances and immunosuppression in broilers. In India the problem of aflatoxicosis is more severe than in the developed countries due tropical and subtropical climatic conditions coupled to great economic losses to the poultry feed conversion. The frequent contamination and chronic exposure of this toxin to poultry causes a heavy economic loss to the farmers. To detoxify the AF, various methods have been tried such as removal of the toxin with the extraction with polar solvents, treatment with oxidizing solvent, 
treatments with oxidizing agents like hydrogen peroxide, which destroys the toxin and using chemicals such as formaldehyde, calcium hydroxide, aldehydes and ammonium hydroxide. However, practical and cost effective methods to detoxify / degrade mycotoxin containing feed stuffs on a larger scale basis are not available. Herbal drugs have been used traditionally in humans by physicians, herbalists and folk healers worldwide or for the prevention and treatment of liver diseases (Pattanayak et al., 2016). Recent research is being focused on this aspect of utilizing plant substances as nutraceuticals in the prevention and treatment of diseases of metabolic and infectious origin both in veterinary and human medicine. Alsophyto-therapy would serve as an alternative safe economical source of curbing loss in production especially in poultry.

Hence, the present experiment has been designed to study the genesis of oxidative stress in poultry due to fungal infections like aflatoxicosis and its alleviation by employing dried powdered rhizome of Curcuma longa (turmeric).

Perusal of literature revealed only scanty reports of turmeric against aflatoxicosis in poultry. Hence, the present investigation has been undertaken to study the ameliorating effect of turmeric powder in induced aflatoxicosis in broiler birds with special reference to biochemical changes and oxidative stress.

\section{Materials and Methods}

\section{Production of aflatoxin}

The AF was produced from Aspergillus flavus NRRL - 18079 pure culture (Institute of Microbial Technology, Chandigarh, India) via fermentation of rice by the method of Shotwell et al., (1966). Fermented rice was then steamed to kill the fungus, dried and ground to fine crystalline powder. Hundred grams of powder from the culture substrate sample was sent to Animal Feed Analytical and Quality Control Laboratory, Veterinary College, Namakkal, Tamilnadu, India for quantification of AF. The AF within the rice powder consisted of $165 \mathrm{ppm}^{\mathrm{AFB}}{ }_{1}, 28 \mathrm{ppm}$ $\mathrm{AFB}_{2}$ and $20 \mathrm{ppm} \mathrm{AFB}_{2}$. The rice powder was added to the basal diet to provide the required amount of $1 \mathrm{ppm}\left(1 \mathrm{mg} \mathrm{kg}^{-1}\right)$.

\section{Collection and preparation of the plant material}

Curcuma longa rhizomewas procured from the local market of Durg, was shade dried and reduced to fine powder using grinder and the powder was stored in airtight containers. The powder thus obtained was used in the present investigation.

\section{Chickens and diet}

The experimental investigation was planned for immunopathological evaluation of protective potential of Cajanus indicus on Aflatoxin induced toxicity in broilers after obtaining approval from Institutional Animal Ethics Committee. Clinically healthy one hundred and sixty eight one-day-old, Cobb400 broiler chicks of both sexes, weighing 48$50 \mathrm{~g}$ were obtained from a commercial hatchery and were reared on deep litter system of housing using rice husk with provision of artificial light at night. The chicks were fed a standard commercial feed starter upto 14 days, thereafter a grower diet upto 28 days and finisher upto 42 days. Chickens were allowed access to the diets and fresh and clean drinking water ad libitum. The basal diets were tested for possible residual AF before feeding and there were no detectable levels present. All the experimental chicks were kept under close observation during entire period of study. 


\section{Experiment design}

Chicks were weighed and randomly allotted into 3 groups of 30 chicks in each group having 3 replicates of 10 chicks in each group. Chicks of group-1 were kept as untreated control and were given only basal diet. Chicks of group -2 were given fed diet with aflatoxin@1 ppm from day first of experiment and considered as experimental aflatoxicosis group. Group-3 birds were fed diet with aflatoxin @1 ppm along with Curcuma longa powder @ $10 \mathrm{gm} / \mathrm{kg}$ of feed as a treatment on mycotoxicosis from day first of experiment.

\section{Biochemical study}

Jugular blood samples were collected in dry evacuated tubes from birds of three groups after 42 days of experimental period. One tube contained sodium fluoride was used for glucose measurement. The second tube of blood was allowed to clot and the separated serum was utilized for total protein and enzymatic activity values. Blood glucose level (Nelson and Somogyi, 1969), total serum protein, albumin, globulin and albumin: globulin (A:G) ratio (Wooton, 1974), aspartate amino transferase (AST) and alanine amino transferase (ALT) (Reitman and Frankel, 1957) and alkaline phosphate (ALP) (Kind and King, 1954) were measured using commercially available kits in biochemistry semi autoanalyzer (RA 50; Bayer Make).Two birds from each replicate were sacrificed and following parameters were studied by standard methods.

\section{Assessment of oxidative stress parameters}

A $500 \mathrm{mg}$ of liver and kidney was weighed and taken in a $5 \mathrm{ml}$ of ice cold PBS (pH 7.4). Another $200 \mathrm{mg}$ of sample was weighed separately and taken in $2 \mathrm{ml}$ of $0.02 \mathrm{M}$ Ethylene Diamine Tetra Acetic acid (EDTA) solution for reduced glutathione (GSH) estimation. The homogenates (10\%) prepared with tissue homogenizer under ice cold condition were centrifuged for $10 \mathrm{~min}$ at 3000 $\mathrm{rpm}$. The supernatant was stored at $-20{ }^{\circ} \mathrm{C}$ until assay of different oxidative stress related biochemical parameters. A double beam UV-VIS spectrophotometer was used for recording the absorbance of the test sample. GSH was determined by estimating the free - $\mathrm{SH}$ groups, using 5-5'- dithiobis 2 nitro benzoic acid (DTNB) method of Sedelak and Lindsay (1968). For estimation of GSH, $10 \%$ homogenate was made in $0.02 \mathrm{M}$ EDTA The extent of lipid peroxidation was measured in terms of MDA (malondialdehyde) production, by the thiobarbituric acid (TBA) method as described by Rehman (1984). The amount of LPO was expressed as nmoles of MDA formed per gram of wet tissue. Activities of catalase enzymes in kidneys and liver homogenates of all the three groups were estimated by UV spectrophotometric method as described by Aebi (1983) and was expressed as $\mathrm{K} / \mathrm{g}$ of wet tissue [ $\mathrm{K}$ is moles $\mathrm{H}_{2} \mathrm{O}_{2}$ utilized / $\mathrm{min} / \mathrm{g}$ of wet tissue]. Protein in liver and the kidney homogenates was determined by the method of Lowry et al., (1951).

\section{Results and Discussion}

\section{Biochemical parameters}

The effects of supplementation of $C$. longa on various biochemical parameters in table 1 and figure 1. The total serum protein level (Mean \pm S.E) observed at $6^{\text {th }}$ week in the control, aflatoxin alone $(1 \mathrm{ppm})$ and C. longa $(1 \%)+$ $\mathrm{AF}(1 \mathrm{ppm})$ treated groups of birds were 5.13 $\pm 0.12,3.58 \pm 0.18,4.32 \pm 0.14(\mathrm{~g} / \mathrm{dl})$, respectively. The albumin, globulin and albumin/globulin ratio levels (Mean \pm S.E) observed at $6^{\text {th }}$ week in the control, aflatoxin alone and C. longa $+\mathrm{AF}$ treated groups of 
birds were $1.73 \pm 0.08,1.01 \pm 0.07,1.35 \pm$ $0.04(\mathrm{~g} / \mathrm{dl}) ; 3.38 \pm 0.07,2.54 \pm 0.13,2.96 \pm$ $0.11(\mathrm{~g} / \mathrm{dl})$ and $0.512 \pm 0.023,0.395 \pm 0.01$, $0.456 \pm 0.011$, respectively. The results indicated that the supplementation of both 1 ppm aflatoxin alone and $C$. longa $(1 \%)+\mathrm{AF}$ (1 ppm) in feed caused a significant decrease $(p<0.01)$ in total serum protein, albumin, globulin, albumin/globulin ratio at $6^{\text {th }}$ week as compared to control but the levels of total serum protein, albumin, globulin, albumin/globulin ratio of the birds in $C$. longa $+\mathrm{AF}$ treated group were significantly higher $(\mathrm{p}<0.01)$ than the AF alone treated group. Total protein and albumin values were significantly reduced in AF treated birds. Vasan et al., (1998) also reported the similar type of reduction in AF fed broilers. Reduction of total protein level suggests a liver/kidney disorder in which protein is not digested or absorbed properly. The lowered serum protein and albumin levels in the current studies support the hypothesis that aflatoxin toxicity is expressed principally through the disruption of transcriptional events, mediated by the metabolites of AF that bind to DNA. As the liver is the main organ involved in protein synthesis, its damage observed in this study could also be a contributing factor for these conditions (Mani et al., 1993). Fernandez et al., (1994) reported that the reduction in protein level in aflatoxicosis was due to the inactivation of biosynthetic enzymes of protein synthesis and impairment of amino acid transport in liver.

Globulin is one of the three types of serum proteins, the others being albumin and fibrinogen. Some globulins are produced in the liver, while others are made by the immune system. The globulin levels are also significantly lowered in the birds fed with AF and similar reductions in the globulin levels were also documented by Kurkure et al., (2001); Priyadarshini and Narasareddy (2010) who attributed the reduced globulins to the depressant effect of AF on protein synthesis. Disease states affect the relative changes in albumin and globulins in different ways. A low $\mathrm{A} / \mathrm{G}$ ratio may reflect overproduction of globulins or underproduction of albumin, such as occurs with cirrhosis, or selective loss of albumin from the circulation, as occurs with kidney disease (nephrotic syndrome). The $\mathrm{A} / \mathrm{G}$ ratio in present study was also differing significantly among all the groups. The reduced $A / G$ ratio in the birds fed with $A F$ alone is due to the impairment of albumin synthesis by the AF. Feeding of the Curcuma longa in broiler as a feed additive enhanced the level of serum total protein and the globulin levels (Kumari et al., 2007). Higher total protein levels in $C$. longa $+\mathrm{AF}$ group, suggested better ability of hepatocytes to synthesize protein. Significantly higher serum globulin level suggested that birds of C. longa treated group had potential for better humoral immune status. The restorative effect exhibited by $C$. longa might be due to neutralization of the action of $\mathrm{AFB}_{\mathrm{I}}$ by curcumin and prevention of aflatoxin induced liver damage (Soni et al., 1992). Similar observations have been reported by Kurkure et al., (2001) with turmeric powder in aflatoxicosis.

The blood glucose values (Mean \pm S.E) observed at $6^{\text {th }}$ week in the control, aflatoxin alone and C. longa with AF treated groups of birds were $177.83 \pm 3.06,172.67 \pm 3.13,176$ $\pm 2.67(\mathrm{mg} / \mathrm{dl})$, respectively. The results showed that there was no significant difference in blood glucose levels among the different treatments. Blood glucose levels in groups fed with AF alone showed a slight numerical reduction than the Control and $C$. longa $+\mathrm{AF}$ treated birds. This is in accordance Priyadarshini and Narasareddy (2010) and the author attributed this decreased glucose levels to reduced levels of glucose-6-phosphatase enzyme. The Serum 
creatinine and uric acid levels(Mean \pm S.E) observed at $6^{\text {th }}$ week in the control, aflatoxin alone and $C$. longa $+\mathrm{AF}$ treated groups of birds were $1.38 \pm 0.05,1.85 \pm 0.08,1.656 \pm$ 0.05 and $8.30 \pm 0.29,11.01 \pm 0.52,9.65 \pm$ 0.45 (mg/dl), respectively.

From the above results, it was evident that the supplementation of $1 \mathrm{ppm}$ aflatoxin alone and supplementation of $C$. longa $(1 \%)+$ the AF (1 $\mathrm{ppm})$ in feed caused a significant increase $(p<0.01)$ in serum creatinine and uric acid levelsat $6^{\text {th }}$ week as compared to control. But the levels of serum creatinine in C. longa + AF treated group of birds were significantly lower $(\mathrm{p}<0.01)$ than the AF alone treated group, whereas, the serum uric acid level did not show significant difference between the $\mathrm{AF}$ alone and $C$. longa $+\mathrm{AF}$ treated group. Uric acid is the primary catabolic product of protein, non-protein nitrogen, and purines in birds. The avian kidney excretes uric acid primarily by tubular secretion, unlike the mammalian system that excretes urea entirely by filtration. The clearance of uric acid by tubular secretion surpasses the glomerular filtration by a factor of 8 or higher, representing 80 to 90 per cent of the total excretion (Skadhauge, 1983). The rate of uric acid excretion is largely independent of the hydration status and rate of urine flow in birds. The rate of uric acid excretion is primarily influenced by the plasma uric acid concentration and renal portal blood flow. A bird in normal nitrogen and acid-base balance will excrete approximately $80 \%$ of the total nitrogen as uric acid, $15 \%$ as ammonia, and 1 to $10 \%$ as urea (Skadhauge, 1983; Goldstein and Skadhauge, 2000). Serum uric acid level increases with loss of two third of the functional renal mass in birds. The increase in the uric acid levels in the AF treated birds in the current study might have resulted from the renal insult caused by AF as evidenced from our pathological studies. Creatinine is not a major non protein nitrogen component of avian blood. Avian presumably lacks the creatine-dehydrogenase enzyme, so the urine contains very little creatinine but much more creatine which is the reverse in case of humans, who excretes creatinine. Therefore, serum creatinine has less reliable value than uric acid in the evaluation of renal function in birds.

The treatment of $C$. longa $(1 \%)+\mathrm{AF}$ reduced significantly the serum creatinine levels and non-significantly the uric acid levels. The present findings are in close agreement with the Gowda et al., (2008). The improvement in the serum creatinine and uric acid levels by the administration of $C$. longa indicates its partial protective effect on the kidneys during the aflatoxicosis. The reduced serum uric acid levels in broilers after turmeric treatment $(1 \mathrm{~g}$ $/ \mathrm{Kg}$ ) as a feed additive was also observed by Kumari et al., (2007). The author also reported higher $\mathrm{Mn}^{++}$levels in turmeric treated birds and this has stimulated the $\mathrm{Mn}^{++}$ dependent enzyme arginase in kidneys and liver, thereby, triggering urea cycle at a higher level. The resultant alteration of nitrogenous waste excretion through the urea cycle might be responsible for the lowered value of serum uric acid. The altered electrolyte balance and acidification of urine due to feeding of $\mathrm{C}$. longa might constitute another pathway responsible for lowered uric acid levels (Kumari et al., 2007). The AST and ALT values (Mean \pm S.E) observed at $6^{\text {th }}$ week in the control, aflatoxin (1 ppm) alone and C.longa (1\%) with AF treated groups of birds were $4.16 \pm 0.31,7.5 \pm 0.43,6.17 \pm 0.40$ $(\mathrm{IU} / \mathrm{L})$ and $253.83 \pm 4.81,277.67 \pm 5.85$, $263.67 \pm 6.93$ (IU/L), respectively. The results showed that the supplementation of 1 ppm aflatoxin alone and supplementation of C. longa (1\%) + AF (1 ppm) in feed caused a significant increase in AST and ALT levels at $6^{\text {th }}$ week as compared to control but the levels of AST and ALT of the birds in $C$. longa + AF treated group were significantly lower than the AF alone treated group. A significant elevation was noticed in activity of 
ALT and AST levels at 42 days post feeding AF endorsing with the findings of Johri et al., (1990), Raina et al., (1991), Shukla and Pachauri (1995) and Mani et al., (2000), Sodhi et al., (2005). Liver is the prime organ affected by aflatoxicosis. The significant increase in the level of both the enzymes might be due to the damage of the hepatocytes, caused by the toxin. This is turn modifies the cellular permeability resulting in the release of enzymes into the serum (Shukla and Pachauri, 1995). Liver and kidney degeneration results in chronic venous congestion with circulatory and degenerative changes in most of the body tissues. This leads to leakage of enzymes and hence an increase in enzyme concentration in the serum (Jindal et al., 1994). Incorporation of C. longa $(1 \%)+\mathrm{AF}$ in feed showed a significant decrease in AST and ALT levels compared to feeding of AF alone. These findings are in harmony with Deshpande et al., (1998), Kurkure et al., (2001) and Ahamadi (2010) who observed similar reduction in AST and ALT levels after feeding curcumin and turmeric respectively. The ability of curcumin to inhibit adduct formation between aflatoxin $\mathrm{B}_{1}$ and DNA due to its strong affinity towards cytochromes (Firozi et al., 1996) partially reduced the hepatotoxicity and hence the enzyme level. It is also proposed that curcumin by virtue of antioxidant properties suppressed the AF induced liver injury and thereby decreasing the AST and ALT levels in aflatoxicosis (Ahamadi, 2010).

However, the supplementation of C. longa powder did not completely restore the serum biochemical alterations induced by the AF, indicating its partial protection.

Table.1 Effects of supplementation of $C$. longa on biochemical parameters at $6^{\text {th }}$ week in induced aflatoxicosis in broiler birds.

\begin{tabular}{|c|c|c|c|c|c|c|c|c|c|}
\hline GROUPS & $\begin{array}{l}\text { Total Serum } \\
\text { Protein } \\
(\mathrm{g} / \mathrm{dl})\end{array}$ & $\begin{array}{l}\text { Albumin } \\
(\mathrm{g} / \mathrm{dl})\end{array}$ & $\begin{array}{l}\text { Globulin } \\
(\mathrm{g} / \mathrm{dl})\end{array}$ & $\begin{array}{l}\text { Albumin/ } \\
\text { globulin } \\
\text { ratio }\end{array}$ & $\begin{array}{l}\text { Blood } \\
\text { glucose } \\
(\mathrm{mg} / \mathrm{dl})\end{array}$ & $\begin{array}{l}\text { Serum } \\
\text { Creatinine } \\
(\mathrm{mg} / \mathrm{dl})\end{array}$ & $\begin{array}{l}\text { Uric acid } \\
(\mathrm{mg} / \mathrm{dl})\end{array}$ & $\begin{array}{l}\text { AST(SGPT) } \\
(\mathrm{IU} / \mathrm{L})\end{array}$ & $\begin{array}{l}\text { ALT(SGOT) } \\
(\mathrm{IU} / \mathrm{L})\end{array}$ \\
\hline Control & $\begin{array}{l}5.13 \\
\pm 0.12^{a}\end{array}$ & $\begin{array}{l}1.73 \\
\pm 0.08^{a}\end{array}$ & $\begin{array}{l}3.38 \\
\pm 0.07^{a}\end{array}$ & $\begin{array}{l}0.512 \\
\pm 0.023^{a}\end{array}$ & $\begin{array}{l}177.83 \\
\pm 3.06\end{array}$ & $\begin{array}{l}1.38 \\
\pm 0.05^{\mathrm{c}}\end{array}$ & $\begin{array}{l}8.30 \\
\pm 0.29^{b}\end{array}$ & $\begin{array}{l}4.16 \\
\pm 0.31^{c}\end{array}$ & $\begin{array}{l}253.83 \\
\pm 4.81^{b}\end{array}$ \\
\hline Aflatoxin & $\begin{array}{l}3.58 \\
\pm 0.18^{c}\end{array}$ & $\begin{array}{l}1.01 \\
\pm 0.07^{\mathrm{c}}\end{array}$ & $\begin{array}{l}2.54 \\
\pm 0.13^{c}\end{array}$ & $\begin{array}{l}0.395 \\
\pm 0.01^{\mathrm{c}}\end{array}$ & $\begin{array}{l}172.67 \\
\pm 3.13\end{array}$ & $\begin{array}{l}1.85 \\
\pm 0.08^{a}\end{array}$ & $\begin{array}{l}11.012 \\
\pm 0.52^{a}\end{array}$ & $\begin{array}{l}7.5 \\
\pm 0.43^{a}\end{array}$ & $\begin{array}{l}277.67 \\
\pm 5.85^{\mathrm{a}}\end{array}$ \\
\hline $\begin{array}{l}\text { Aflatoxin } \\
+ \text { Turmeric }\end{array}$ & $\begin{array}{l}4.32 \\
\pm 0.14^{\mathrm{b}}\end{array}$ & $\begin{array}{l}1.35 \\
\pm 0.04^{b}\end{array}$ & $\begin{array}{l}2.96 \\
\pm 0.11\end{array}$ & $\begin{array}{l}0.456 \\
\pm 0.011^{b}\end{array}$ & $\begin{array}{l}176 \\
\pm 2.67 \\
\end{array}$ & $\begin{array}{l}1.656 \\
\pm 0.05^{b}\end{array}$ & $\begin{array}{l}9.65 \\
\pm 0.45^{\text {ab }}\end{array}$ & $\begin{array}{l}6.17 \\
\pm 0.40^{\mathrm{b}}\end{array}$ & $\begin{array}{l}263.67 \\
\pm 6.93^{c} \\
\end{array}$ \\
\hline $\begin{array}{l}\text { Level of } \\
\text { significance }\end{array}$ & $* *$ & $* *$ & $* *$ & $* *$ & NS & $* *$ & $* *$ & $* *$ & $*$ \\
\hline
\end{tabular}

Values are mean \pm SE of 6 observations $(n=6)$

Mean with different superscript in column wise are differing significantly

$* * \mathrm{P}<0.01, * \mathrm{P}<0.05, \mathbf{N S}-$ Non Significant

Table.2 Effects of supplementation of $C$. longa on oxidative stress parameters in liver at $6^{\text {th }}$ week in induced aflatoxicosis in broiler birds.

\begin{tabular}{|l|l|l|l|l|}
\hline Groups & $\begin{array}{l}\text { Tissue protein }(\mathrm{mg} / \\
\text { g of wet tissue) }\end{array}$ & $\begin{array}{l}\text { Reduced Glutathione (mmole } \\
\text { GSH/g tissue) }\end{array}$ & $\begin{array}{l}\text { LPO (nmole MDA } \\
\text { formed/g tissue) }\end{array}$ & $\begin{array}{l}\text { Catalase (mmole } \mathrm{H}_{2} \mathrm{O}_{2} \\
\text { utilized/min/mg protein) }\end{array}$ \\
\hline Control & $126.55 \pm 3.47^{\mathrm{a}}$ & $0.470 \pm 0.015^{\mathrm{a}}$ & $209.15 \pm 7.78^{\mathrm{c}}$ & $164.83 \pm 5.74$ \\
\hline Aflatoxin & $97.13 \pm 4.51^{\mathrm{b}}$ & $0.359 \pm 0.016^{\mathrm{c}}$ & $293.16 \pm 5.75^{\mathrm{a}}$ & $162.53 \pm 7.42$ \\
\hline Turmeric + Aflatoxin & $102.98 \pm 4.11^{\mathrm{b}}$ & $0.412 \pm 0.015^{\mathrm{b}}$ & $255.38 \pm 5.76^{\mathrm{b}}$ & $173.90 \pm 11.66$ \\
\hline
\end{tabular}

Values are mean \pm SE of 6 observations $(n=6)$

Mean with different superscript in column wise are differing significantly $(\mathrm{P}<0.01)$ 
Tabl.3 Effects of supplementation of $C$. longa on oxidative stress parameters in kidneys at $6^{\text {th }}$ week in induced aflatoxicosis in broiler birds

\begin{tabular}{|l|l|l|l|l|}
\hline Groups & $\begin{array}{l}\text { Tissue protein }(\mathrm{mg} / \\
\mathrm{g} \text { of wet tissue) }\end{array}$ & $\begin{array}{l}\text { Reduced Glutathione } \\
(\mathrm{mmole} G S H / g \text { tissue) }\end{array}$ & $\begin{array}{l}\text { LPO (nmole MDA } \\
\text { formed/g tissue) }\end{array}$ & $\begin{array}{l}\text { Catalase (mmole } \mathrm{H}_{2} \mathrm{O}_{2} \\
\text { utilized/min/mg protein) }\end{array}$ \\
\hline Control & $98.01 \pm 5.27$ & $0.489 \pm 0.0047^{\mathrm{a}}$ & $160.85 \pm 11.03^{\mathrm{b}}$ & $170.76 \pm 1.83$ \\
\hline Aflatoxin & $89.45 \pm 2.75$ & $0.430 \pm 0.0063^{\mathrm{b}}$ & $211.11 \pm 12.93^{\mathrm{a}}$ & $166.38 \pm 7.28$ \\
\hline Turmeric + Aflatoxin & $103.36 \pm 4.29$ & $0.452 \pm 0.0102^{\mathrm{b}}$ & $204.79 \pm 6.14^{\mathrm{a}}$ & $184.25 \pm 8.63$ \\
\hline
\end{tabular}

Values are mean \pm SE of 6 observations $(n=6)$

Mean with different superscript in column wise are differing significantly $(\mathrm{P}<0.01)$

Fig.1 Effects of supplementation of $C$. longa on biochemical parameters at $6^{\text {th }}$ week in induced aflatoxicosis in broiler birds
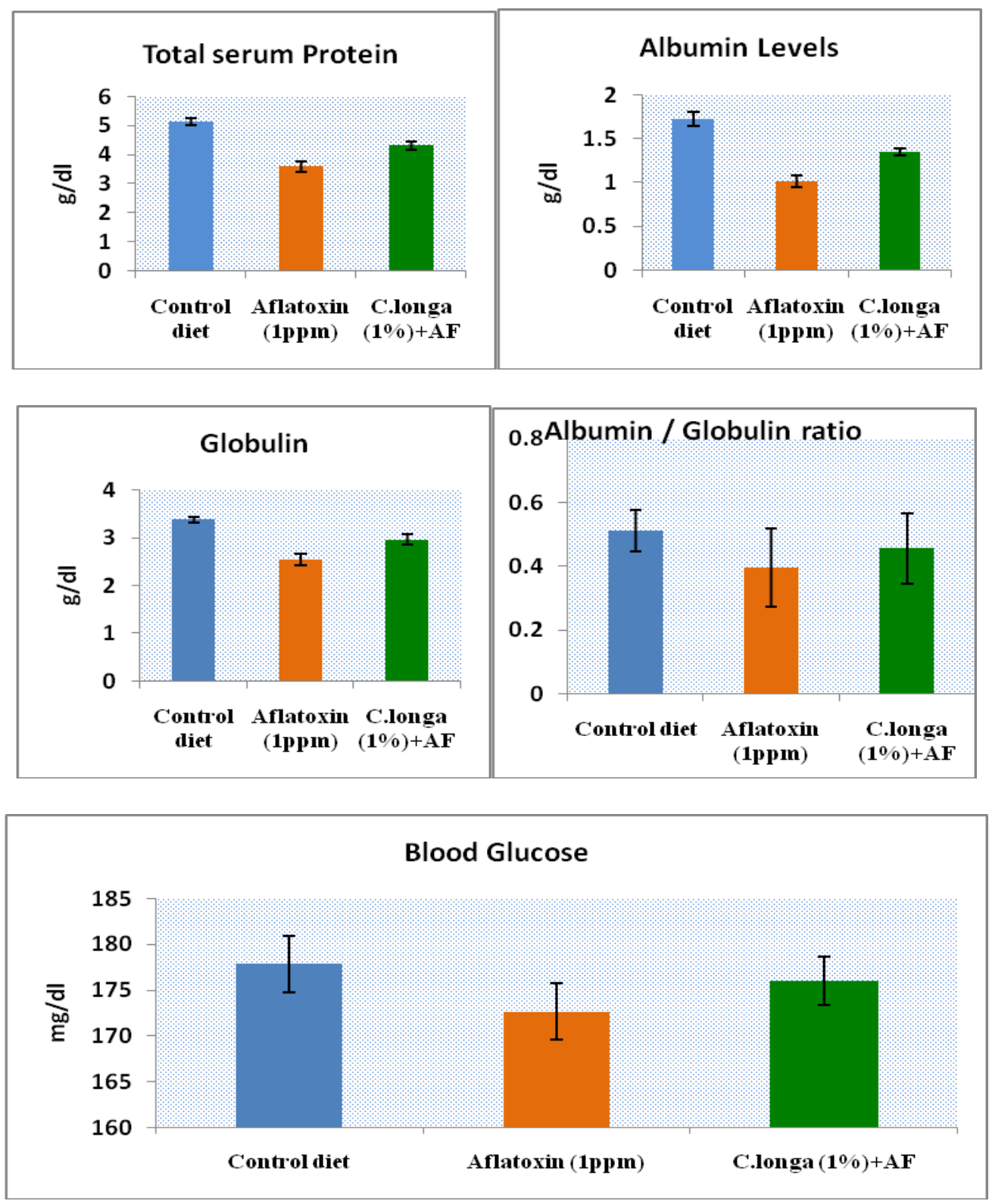

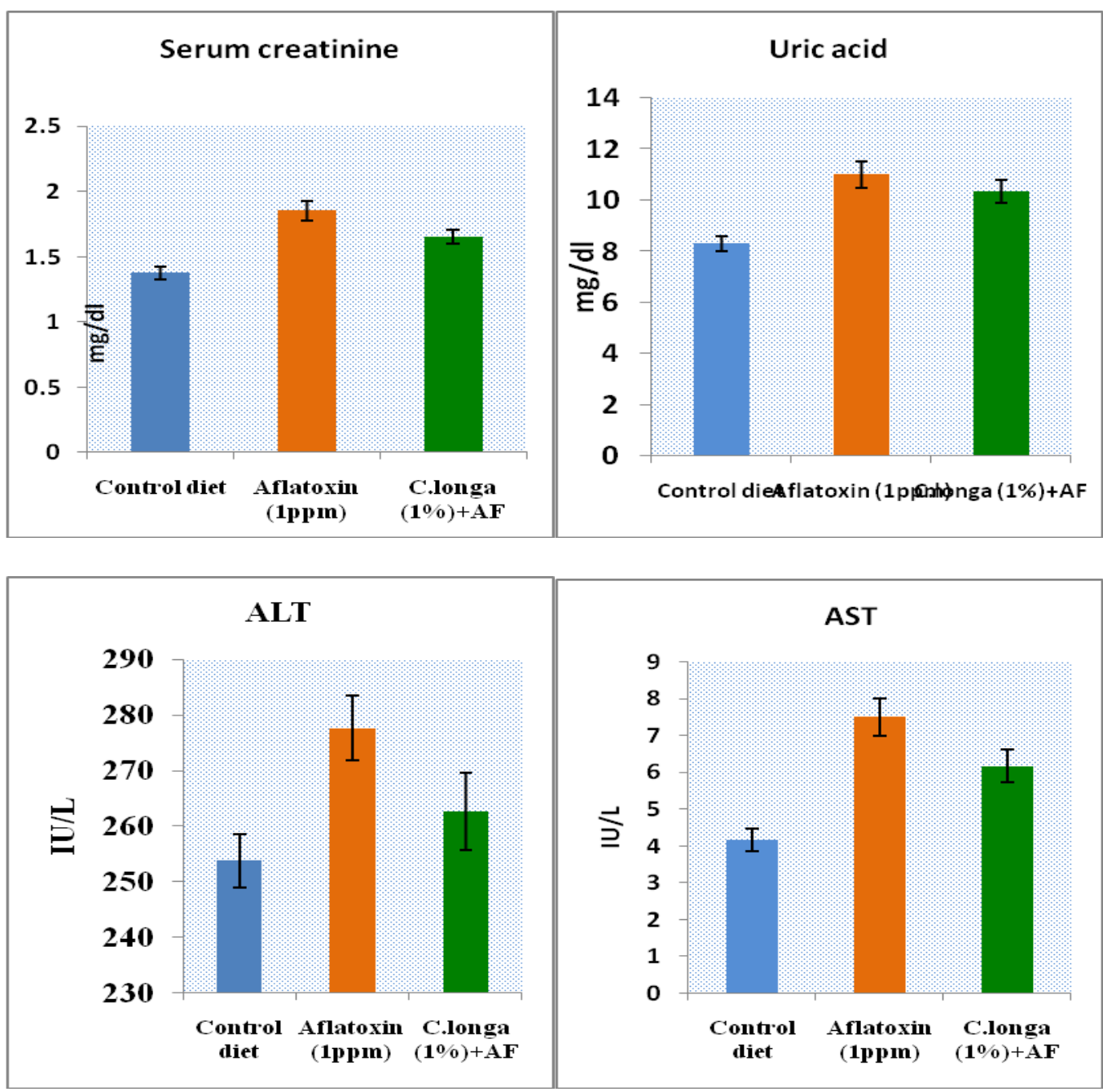

Fig.2 Effects of supplementation of $C$. longa on oxidative stress parameters in liver and kidneys at $6^{\text {th }}$ week in induced aflatoxicosis in broiler birds

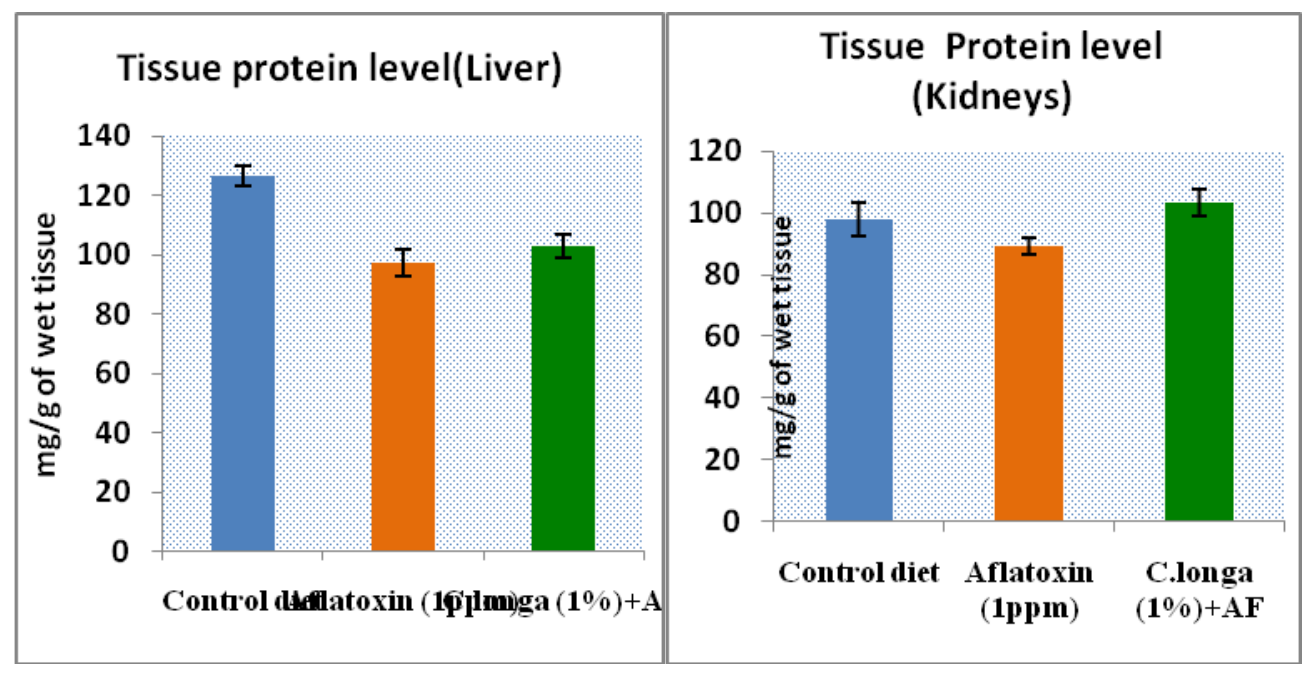



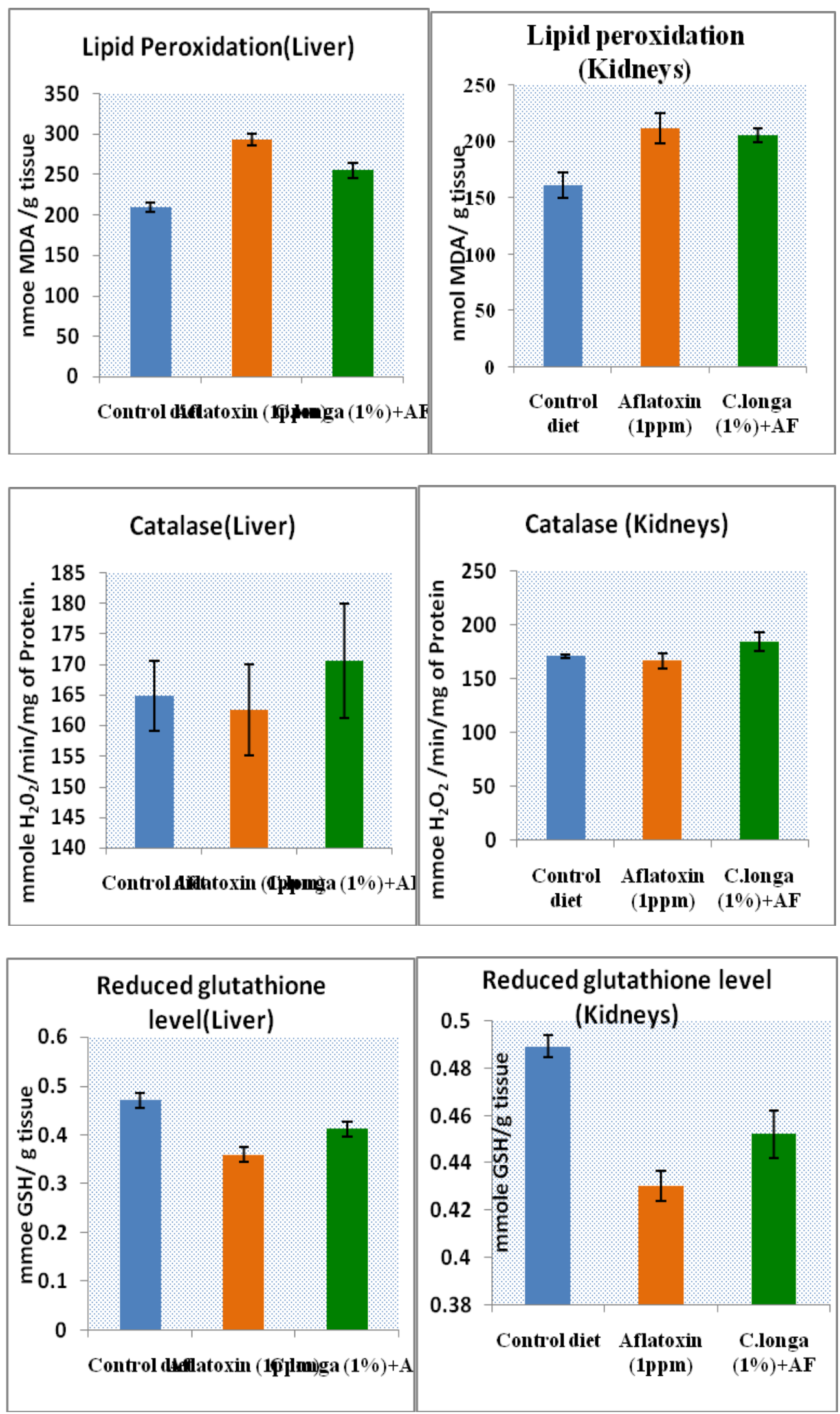


\section{Stress parameters}

The effects of supplementation of C. longa on various antioxidant parameters like lipid peroxidation, reduced glutathione, catalase and tissue protein levels in the liver and kidneys in induced aflatoxicosis in broiler birds were presented in tables 2 and 3 and figures 2 and 3. The lipid peroxidation (LPO) levels (Mean \pm S.E) observed at $6^{\text {th }}$ week in the liver and kidneys of control, aflatoxin alone $(1 \mathrm{ppm})$ and C. longa $(1 \%)+\mathrm{AF}(1$ ppm) treated groups of birds were $209.15 \pm$ $7.78,293.16 \pm 5.75,255.38 \pm 5.76$ and 160.85 $\pm 11.03,211.11 \pm 12.93,204.79 \pm 6.14$ (nmole MDA formed/g tissue), respectively. The results showed that the incorporation of 1 ppm aflatoxin alone and supplementation of C. longa $(1 \%)+$ the AF (1 ppm) in feed caused a significant increase $(p<0.01)$ in the lipid peroxidation in both liver and kidneys at $6^{\text {th }}$ week as compared to control. The levels of lipid peroxidation in liver of the birds in $C$. longa $+\mathrm{AF}$ treated group were significantly lower $(\mathrm{p}<0.01)$ than the AF alone treated group. However, the LPO levels in the kidneys showed no significant difference between the $\mathrm{AF}$ alone and the $C$. longa $+\mathrm{AF}$ treated group.

The tissue protein levels (Mean \pm S.E) observed at $6^{\text {th }}$ week in the liver and kidneys of control, aflatoxin alone $(1 \mathrm{ppm})$ and $C$. longa $(1 \%)+\mathrm{AF}(1 \mathrm{ppm})$ treated groups of birds were $126.55 \pm 3.47,97.13 \pm 4.51$, $102.98 \pm 4.11$ and $98.01 \pm 5.27,89.45 \pm 2.75$ $103.36 \pm 4.29$ (mg/ g of wet tissue), respectively. From the above results, it was observed that the supplementation of $1 \mathrm{ppm}$ aflatoxin alone and supplementation of $C$. longa $(1 \%)+\mathrm{AF}(1 \mathrm{ppm})$ in feed caused a significant decrease $(\mathrm{p}<0.01)$ in the liver protein content at $6^{\text {th }}$ week as compared to control but the levels of protein in liver of the birds in C. longa $+\mathrm{AF}$ treated group were numerically higher than the AF alone treated group. However, the protein level in the kidneys showed no significant difference among the different treatments.

The deleterious effects are considered to be caused by free radicals ( $\left.\mathrm{ROO}^{\circ}, \mathrm{RO}^{\circ}, \mathrm{OH}^{*}\right)$ produced during peroxide formation from fatty acids containing methylene interrupted double bond, i.e., those found in the naturally occurring poly unsaturated fatty acids. Lipid peroxidation is a chain reaction providing a continuous supply of free radicals that initiate further peroxidation (Harper, 2003). Since, the ROS production is a natural process, and persistent high levels of ROS could be damaging the cell and its membrane, nature has developed antioxidant systems aimed at their neutralization. A variety of enzymatic and non-enzymatic mechanisms have evolved to protect cells against ROS. These enzymatic antioxidants include superoxide dismutase, catalase, GSH peroxidase system, peroxiredoxins and glutathione peroxidase, whose function is to detoxify peroxides. Further, ceruloplasmin and ferritin help remove metals, such as iron, that promote oxidative reactions. Therefore, an increase in lipid peroxidation could be due to significant reduction in the activities of enzymatic antioxidants as well as non-enzymatic antioxidants in the liver and kidneys of aflatoxin-treated rat (Verma and Mathuria, 2008). Superoxide dismutase protects cells from oxidative damage by breaking down a potentially hazardous free radical superoxide to $\mathrm{H}_{2} \mathrm{O}_{2}$ and $\mathrm{O}_{2}$. The $\mathrm{H}_{2} \mathrm{O}_{2}$ produced can then be decomposed enzymatically by catalase and glutathione peroxidase (GSH-Px) into $\mathrm{H}_{2} \mathrm{O}$. Thus reduction in the enzyme activities like catalase and significant reduction in reduced glutathione levels in liver and kidneys of birds treated with AF observed in the current study could be responsible for increased lipid peroxidation. Significant reductions in glutathione peroxidase, superoxide dismutase, catalase and corresponding increase in LPO have been also reported in aflatoxin-fed rat liver and kidney (Sharma, et al., 2011).The 
decline in enzymatic antioxidants could be due to the reduction in protein biosynthesis as evident from the reduced tissue protein levels as observed in the present studies. In addition, oxidative stress may result in damage to critical cellular macromolecules including DNA, lipids and proteins. Cellular fatty acids are readily oxidized by ROS to produce lipid peroxyl radicals which can subsequently propagate into MDA, may result in interaction with cellular DNA-MDA adducts (Shen et al., 1994) and there by interfering in the transcription and translation process. Proteins are also easily attacked by ROS directly or indirectly through lipid peroxidation modifying their enzyme activity (Clayson et al., 1994). The above mechanisms(s) might be responsible for the reduced liver and kidney protein levels observed in the current study.

The reduced glutathione (GSH) levels (Mean \pm S.E) observed at $6^{\text {th }}$ week in the liver and kidneys of control, aflatoxin alone (1 ppm) and $C$. longa $(1 \%)+\mathrm{AF}$ treated groups of birds were $0.470 \pm 0.015,0.359 \pm 0.016$, $0.412 \pm 0.015$ and $0.489 \pm 0.0047,0.430 \pm$ $0.0063,0.452 \pm 0.0102$ (mmole GSH/g tissue), respectively. The results reported herein indicated that the supplementation of both $1 \mathrm{ppm}$ aflatoxin alone and C. longa $(1 \%)$ $+\operatorname{AF}(1 \mathrm{ppm})$ in feed caused a significant decrease $(\mathrm{p}<0.01)$ in the reduced glutathione (GSH) levels in both liver and kidneys at6 weeks as compared to control but the levels of GSH in liver of the birds in C. longa $+\mathrm{AF}$ treated group was significantly higher $(\mathrm{p}<0.01)$ than the AF alone treated group. However, the GSH levels in the kidneys showed no significant difference between the $\mathrm{AF}$ alone and the $C$. longa $+\mathrm{AF}$ treated group. In the current studies, reduced glutathione content was decreased significantly in liver and kidney of aflatoxintreated birds, suggesting its rapid oxidation. Similar results have been obtained by the Verma and Mathuria (2008) and Sharma et al., (2011) in aflatoxin treated mice.
Glutathione has a beneficial effect by virtue of possessing - SH groups. It helps to protect biological membranes, which are readily susceptible to injury by peroxidation (Venkateshwaran et al., 1987) by donating the -SH groups to the reactive oxygen species (ROS) and thereby becoming oxidized glutathione (GSSH). This reaction is catalysed by the enzyme Glutathione-STranferase (GST). The conversion of oxidized glutathione (GSSH) into reduced glutathione (GSH) is catalysed by the enzyme glutathione reductase (GR) along with the NADPH. Any change in this process will reduce the GSH content of the liver/ kidney which results in the poor free radical scavenging. In the present study, there is a significant reduction of the GSH in the aflatoxin group which may be due to the overload of AF generated free radicals, that may deplete the glutathione through conjugation activities (Percival, 1997) or may be due to the down regulation of the genes coding for GR and GST (Yarru et al., 2009), thereby reducing the GSH levels, resulting in the tissue injury.

The catalase (CAT) levels (Mean \pm S.E) observed at $6^{\text {th }}$ week in the liver and kidneys of control, aflatoxin alone (1 ppm) and $C$. longa $(1 \%)+\mathrm{AF}(1 \mathrm{ppm})$ treated groups of birds were $164.83 \pm 5.74,162.53 \pm 7.42$, $173.90 \pm 11.66$ and $170.76 \pm 1.83,166.38 \pm$ 7.28, $184.25 \pm 8.63$ (mmole $\mathrm{H}_{2} \mathrm{O}_{2}$ utilized $/ \mathrm{min} / \mathrm{mg}$ protein), respectively. The results showed that there was non-significant difference in catalase (CAT) levels in both liver and kidneys among the different treatments. The breakdown of hydrogen peroxide on the inner mitochondrial membrane and within the mitochondrial matrix causes site-specific damage of critical matrix targets, while the decomposition of hydrogen peroxide outside the mitochondria may cause damage to the outer mitochondrial membrane itself and/or cytosolic targets within the area of diffusion of the hydroxyl radical. Though there is a numerical 
difference in the level of catalase enzyme among the three treatment groups it is not statistically different in the current study. An insignificant effect of AF (1 ppm) on catalase gene expression in broilers was also confirmed by the Yarru et al., (2009).

The improvement in birds supplemented with C. longa $(1 \%)+\mathrm{AF}$ at the $6^{\text {th }}$ week reflects that the $C$. longa is improving the overall performance by modulating the antioxidant status of the liver and the kidneys. The results show that supplementation of Curcuma longa $(1 \%)+$ aflatoxin $(1 \mathrm{ppm})$ partially restored the $\mathrm{AF}$ induced change in protein levels in the serum, liver and kidneys of birds. The improvement in protein levels might be due to increased DNA synthesis and reduction in harmful adduct formation and the biotransformation of the aflatoxin in the liver and this effect was also confirmed by Sharma et al., (2011), Ahamadi (2010). In the current study, decreased GSH levels due to AF might be improved by the inclusion of $C$. longa (1\%) which is evident from the increased GSH levels observed in the birds treated with C. longa (1\%) as compared to birds treated with AF alone. The effect of turmeric supplementation caused a numerical increase in the level of catalase enzyme which is consistent with the earlier works of Ahamadi (2010). Increase in the catalase levels might be responsible for mitigating the hydrogen peroxide radicals generated due to the aflatoxin. Earlier studies reported that curcumin reduced iron-induced hepatic damage, aflatoxin induced mutagenicity and hepatocarcinogenicity (Osawa, 2007). Curcumin is the main component of turmeric, and two minor components are also present as curcuminoids. Curcuminoids possess antioxidant activity (Strimpakos and Sharma, 2008) and the carbonyl functional group of curcuminoids was responsible for its antimutagenic and anticarcinogenic actions (Chun et al., 1999). They protect DNA against oxidative attack, thereby lowering the risk for mutations and other genetic damage (Hatcher et al., 2008; Garcea et al., 2005). They also activate detoxification enzymes such as glutathione S-transferase (Subudhi et al., 2009). Curcumins can down-regulate NF$\kappa \mathrm{B}$, a nuclear transcription factor and critical upstream regulator of genes that control acute and chronic inflammation cascades (Singh and Aggarwal, 1995; Sarkar et al., 2008). It inhibits extracellular matrix formation by enhancing HSC matrix metalloproteinase expression via PPAR $\gamma$ and suppresses connective tissue growth factor expression (Ma et al., 2008). Further, earlier reports suggest that curcumin has a strong inhibitory action on superoxide anion generation (Iqbal et al., 2003), biotransformation of $\mathrm{AFB}_{1}$ to aflatoxicol in liver (Lee et al., 2001) and reduce the formation of adducts through modulation of cytochrome $\mathrm{P}_{450}$ function (Soni et al., 1997). The above findings demonstrated the possible mode of action of curcumin as an antioxidant and there are important interactions among the activities of several antioxidant enzymes, $C$. longa and various ROS and cellular reactions, all of which could be responsible for some of the beneficial effects on the oxidativeantioxidative system observed in the current study.

Results obtained in the present study suggest that $C$. longa caused only partial protection against aflatoxicosis. The reason for incomplete amelioration might be, oxidative stress mediated damage is not the only the mode of action of $\mathrm{AFB}_{1}$ but also the $\mathrm{AF}$ has also been shown to decrease the expression of hepatic genes involved in the energy production and fatty acid metabolism, detoxification, coagulation and immune protection of the broilers (Ahamadi, 2010; Yarru et al., 2009) and the Curcuma may not able to restore all the changes induced by the $\mathrm{AF}$ at various levels. It was reported that addition of Curcuma longa powder in the rations caused significant increase in body 
weight gain and blood $\mathrm{Hb}$ concentration of broilers (Sethy et al., 2016). The action of Curcuma longa depends upon the total curcuminoid content and the oral bio availability of curcumin (Luper, 1999; Ireson et al., 2001).

\section{References}

Ahamadi, F., 2010. Effect of turmeric (Curcuma longa) powder on performance, oxidative stress state and some of blood parameters in broiler fed on diets containing Aflatoxin $\mathrm{B}_{1}$. Global Veterinaria. 5(6): 312-317.

Chun, K., Sohn Y, Kim H, Kim O, Park K, Lee J, Moon A, Lee S, Surh Y. 1999. Antitumor promoting potential of naturally occurring diarylheptanoids structurally related to curcumin. Mutation Res. 428: 49-57.

Clayson, D.B., Mehta R, Iverson F. 1994. Oxidative DNA damage - The effects of certain genotoxic and operationally nongenotoxic carcinogens. Mutat Res. 317: 25-42.

Fernandez, A., Verde MT, Gascon M, Ramos J, Gomez G, Luco DF, Chavez G.1994. Variations of clinical and biochemical parameters of laying hens and broiler chicken fed aflatoxin containing feed. Avian Path. 23: 37-47.

Garcea, G., Berry DP, Jones DJ, Singh R, Dennison AR, Farmer PB, Sharma RA, Steward WP, Gescher AJ. 2005. Consumption of the putative chemopreventive agent curcumin by cancer patients: assessment of curcumin levels in the colorectum and their pharmacodynamic consequences. Cancer Epidemiol Biomarkers Prev.14: 120-125.

Goldstein, D.L., Skadhauge E. 2000. Renal and extrarenal regulation of body fluid composition. In: Whittow GC, ed. Sturkie's Avian Physiology. San Diego,
Calif: Academic Press. pp: 265-298.

Gowda, N.K.S., Ledoux DR, Rottinghaus GE, Bermudez AJ, Chen YC. 2008. Efficacy of turmeric (Curcuma longa), containing a known level of curcumin, and a hydrated sodium calcium aluminosilicate to ameliorate the adverse effects of aflatoxin in Broiler Chicks. Poult Sci. 87: 1125-1130.

Harper, A.H., 2003. Harpers Illustrated Biochemistry, ed by Murray, R.K., Granner, D.K., Mayes, P. and Rodwell, W. $26^{\text {th }}$ ed. Lange publications, pp: 118 119.

Hatcher, H., Planalp R, Cho J, Torti FM, Torti SV. 2008. Curcumin: from ancient medicine to current clinical trials. Cell Mol Life Sci. 65: 1631-1652.

Iqbal, M., Sharma SD, Okazaki Y, Fujisawa M, Okada S. 2003. Dietary supplementation of curcumin enhances antioxidant and phase-I metabolizing enzymes in ddY male mice: Possible role in protection against chemical carcinogenesis and toxicity. Pharmacol Toxicol. 92: 33-38.

Ireson, C., Orr S, Jones DJ. 2001. Characterization of metabolites of the chemopreventive agent curcumin in human and rat hepatocytes and in the rat in vivo, and evaluation of their ability to inhibit phorbol bester-induced prostaglandin $\mathrm{E}_{2}$ production. Cancer Res.61: 1058-1064.

Jindal, N., Mahipal SK, Mahajan NK. 1994. Effect of hydrated sodium calcium aluminosilicate on prevention of aflatoxicosisin broilers. Indian J Anim Sci.63: 649-652.

Johri, T.S., Sadagopan VR, Shrivastava HP, Majumdar S. 1990. Effect of dietary aflatoxin on the performance of purebred broiler chick. Indian J Anim Sci. 60(10): 1246-1248.

Kind, P.R.M., King EJ. 1954. Estimation of serum alkaline phosphatase activity by 
colorimetric methods. J Clin Pathol. 7: 322.

Kumari, P., Gupta MK, Ranjan R, Singh KK, Yadav R.2007.Curcuma longa as feed additive in broiler birds and its pathophysiological effects. Indian J Exp Biol. 45: 272-277.

Kurkure, N.V., Pawar SP, Kognole SM, Gaonorkar AG, Bhanderkar AG, Kalorey DR. 2001. Prevention of aflatoxin induced toxicity by turmeric in cockreals haematology and biochemical study. Indian J Vet Res. 10: 35-40.

Lee, SE, Campbell BC, Russel J, Molyneux C, Hasegawa S, Lee HS. 2001. Inhibitory effects of naturally occurring compounds on aflatoxin $\mathrm{B}_{1}$ biotransformation. J Agril Food Chem. 49: 5171-5177.

Lowry, O.H., Rosebrough NJ, Farr AL, Randall RJ. 1951. Protein measurement with the folin phenol reagent. J BiolChem. 193: 265-275.

Luper, S., 1999. A Review of plants used in the treatment of Liver disease: Part Two. Alt Med Rev. 4(3): 178-188.

Ma, C., Liu WY, Cui Q, Gu CH, Dou YW, Zhao R, Chen M, Zheng $X$. 2008.Effects of intensive insulin therapy on plasma nitric oxide and endothelin-1 levels in patients undergoing cardiac surgery under cardiopulmonary bypass. Zhonghua Waike Zazhi. 46: 443-445.

Mani, K., Sundaresan K, Viswanathan K. 2000.Effect of dietary aflatoxin $\mathrm{B}_{1}$ on the blood constituents in commercial broilers. Indian Vet J. 77: 993-995.

Osawa, T., 2007. Nephroprotective and hepatoprotective effects of curcuminoids. Adv Exp Med Biol 595: 407- 423.

Pattanayak, S., Mandal TK, Bandyopadhyay SK. 2016. Ethnomedicinal study of plants used for protection and stimulation of liver in southern West
Bengal, India. Explor Anim Med Res. 6(2): 164-178.

Percival, M., 1997. Phytonutrients and detoxification. Clinical Nutrition Insights. 5: 1-4.

Priyadarshni, C.H., Narasareddy GV. 2010. Amelioration of toxic effects of aflatoxin and citrinin by adsorbents in broilers. Indian Vet J. 87: 23-25.

Raina, J.S., Roy KS, Singh B. 1991. Biochemical and histochemical studies in experimental mycotoxicosis in chicks. Indian J Anim Sci. 62(2): 12761281.

Rehman, S., 1984. Lead induced regional lipid peroxidation in brain. Toxicol Lett. 21: 333-337.

Reitman, S., and Frankel S. 1957.A colorimetric method for the determination of ALT and AST. American J ClinPathol. 28: 56-63.

Sarkar, F.H., Li Y, Wang Z, Kong D. 2008. $\mathrm{NF}-\kappa \mathrm{B}$ signalling pathway and its therapeutic implications in human diseases. International Rev Immunol. 27: 293-319.

Sedlak, J., Lindsay RH.1968. Estimation of total, protein-bound and non-protein bound sulfhydryl groups in tissue with Ellman's reagent. Anal Biochem. 25:192-205.

Sethy, K., Swain P, Behera K, Nayak SM, Barik SR, Patro P, Meher P. 2016. Effect of turmeric (Curcuma longa) supplementation on growth and blood chemistry of broilers. Explor Anim Med Res. 6(1): 75-79.

Sharma, V., Sharma C, Paliwal R, Pracheta D, Sharma S. 2011. Ameliorative effects of Curcuma longa and curcumin on aflatoxin $\mathrm{B}_{1}$ induced serological and biochemical changes in kidney of male mice. Asian J Biochem Pharma Res. 2(1): 2231-2560.

Shen, H.M., Shi CY, Lee HP, Ong CN. 1994. Aflatoxin $\mathrm{B}_{1}$ induced lipid peroxidation 
in rat liver. Toxicol Appl Pharmacol. 127: $145-150$.

Shotwell, D.L., Hesseltine CW, Stubblefield RD, Sorenson GW. 1966. Production of aflatoxin on rice. Appl Microbiol.14: $425-428$

Shukla, S.K., Pachauri SP. 1995. Blood biochemical profiles in induced aflatoxicosis of cockerels. British Poult Sci. 36: 155-160.

Singh, S., Aggarwal BB. 1995. Activation of transcription factor NF- $\kappa \mathrm{B}$ is suppressed by curcumin (diferuloylmethane). J Biol Chem. 270: 24995-25000.

Skadhauge, E., 1983. Formation and composition of urine. In: Physiology and Biochemistry of the Domestic Fowl, Vol. IV. ed. by Freeman, B.M., Academic Press, London. pp. 108-135.

Sodhi, S., Brar APS, Ghai JK, Brar RS. 2005. Biochemical and immunological effects of dietary exposure to aflatoxin $\mathrm{B}_{1}$. In broiler chicks. Indian $\mathrm{J}$ Poult Sci. 40(2):155-157.

Soni, K.B., Lahiri PM, Chackradeo S, Bhide V, Kuttan R. 1997. Protective effect of food additives on aflatoxin-induced mutagenicity and hepato carcinogenicity. Cancer Lett. 115: 129133.

Soni, K.B., Rajna A, Kuttan R. 1992. Reversal of aflatoxin induced liver damage by turmeric and curcumin. Cancer Lett. 66: 115-121.

Strimpakos, A.S., Sharma RA. 2008. Curcumin: preventive and therapeutic properties in laboratory studies and clinical trials. Anti Oxid Redox Signal.10: 511-545.

Subudhi, U., Das K, Paital B, Bhanja S, Chainy GB. 2009. Supplementation of curcumin and vitamin $\mathrm{E}$ enhances oxidative stress, but restores hepatic histoarchitecture in hypothyroid rats. Life Sci. 84: 372-379.

Vasan, P., Ravi R, Purushothaman MR. 1998. Effect of feeding graded levels of aflatoxin $\left(\mathrm{AFB}_{1}\right)$ on performance of broiler chicken. Indian $\mathrm{J}$ Poult Sci. 33(2): 214-216.

Venkateshwaran, P.S., Millman I, Blumberg BS.1987. Historical treatment of chronic hepatitis B and chronic hepatitis C Proc Natl Acad Sci, USA. 84: S69S73.

Verma, R.J., Mathuria N. 2008.Curcumin ameliorates aflatoxin induced lipid peroxidation in liver and kidney of mice. Acta Pol Pharm Drug Res. 65(2): 195-202.

Wooton, I.D.P., 1974. Estimation of protein biuret. In: microanalysis in medicinal biochemistry. $\quad 5^{\text {th }}$ ed; Churchill Livingstone, Edinburgh and London. pp: 156-158.

Yarru, L.P., Settivari RS, Antoniou E, Ledoux DR, Rottinghaus GE. 2009 . Toxicological and gene expression analysis of the impact of aflatoxin $\mathrm{B}_{1}$ on hepatic function of male broiler chicks. Poult Sci. 88: 360-371.

\section{How to cite this article:}

Raja, L., Chandan Kumar Singh, M. Mondal, S. Nety and Koley, K.M. 2017. Evaluation of Protective Potential of Curcuma longa in Induced Aflatoxicosis in Broiler Birds. Int.J.Curr.Microbiol.App.Sci. 6(10): 72-86. doi: https://doi.org/10.20546/ijcmas.2017.610.009 